\title{
PRAVO OKRIVLJENIKA NA TUMAČENJE I PREVOĐENJE U KAZNENOM POSTUPKU KROZ PRIZMU RECENTNE PRAKSE EUROPSKOG SUDA ZA LJUDSKA PRAVA I SUDA EU-a
}

Doc. dr. sc. Martina Bajčić*

UDK: 343.131.7(4)EU

341.231.14(4):343.131.7

DOI: 10.3935/zpfz.69.2.03

Pregledni znanstveni rad

Primljeno: studeni 2018.

Prema članku 6. Europske konvencije za zaštitu ljudskih prava svatko optužen za kazneno djelo ima pravo na besplatnu pomoć tumača ako ne govori jezikom postupka. Iako su sve države članice EU-a potpisale i ratificirale Konvenciju, zamjetne su razlike u načinu i razini ostvarivanja prava na pomoć tumača zajamčenog Konvencijom, ali i u razini zaštite minimalnih prava Direktive 2010/64 o pravu na tumačenje i prevođenje. Upravo iz tog razloga sudska praksa ima ključnu ulogu ne samo u smanjivanju postojećih razlika, već $i$ u pojačavanju uzajamnog povjerenja u kaznenopravne sustave drugih država članica. U radu se analiziraju nedavne presude Europskog suda za ljudska prava i Suda EU-a koje su prokrčile put konkretiziranju pravnih standarda Konvencije te nekih poroznih odredaba Direktive 2010/64 o pravu na tumačenje i prevođenje. Predlažu se konkretne radnje koje države članice moraju nastaviti poduzimati kako bi osigurale potpunu djelotvornost prava na besplatnu pomoć tumača osumnjičenicima i okrivljenicima u kaznenom postupku.

Ključne riječi: pravo na tumačenje i prevođenje, kazneni postupak, Direktiva $2010 / 64$

\footnotetext{
Dr. sc. Martina Bajčić, docentica Pravnog fakulteta Sveučilišta u Rijeci, Hahlić 6, Rijeka; martina.bajcic@pravri.hr;

ORCID ID: orcid.org/0000-0003-0654-6779
} 


\section{UVOD **}

Iako i čl. 6. Europske konvencije za zaštitu ljudskih prava (dalje u tekstu: EKLJP) i čl. 47. Povelje Europske unije o temeljnim pravima (dalje u tekstu: Povelja) jamče pravo na pravično suđenje ${ }^{1}$, iskustvo je upozorilo na razlike između država članica glede ostvarivanja zaštite prava okrivljenika jer EKLJP i praksa Europskog suda za ljudska prava (dalje u tekstu: ESLJP) pružaju slobodu u načinu na koji će države standarde zaštite temeljnih ljudskih prava ugraditi u svoje nacionalne kaznenopravne sustave. ${ }^{2}$ Radi dosljednije provedbe prava i jamstava utvrđenih člankom 6. EKLJP-a, Komisija je u travnju 2004. objavila Prijedlog Okvirne odluke o nekim postupovnim pravima u kaznenom postupku u EU-u. ${ }^{3}$ Premda nije postignut dogovor između država članica, Komisija je na temelju čl. 82. Ugovora o funkcioniranju Europske unije (dalje u tekstu: UFEU) ${ }^{4}$ predložila prvi zakonodavni instrument u području kaznenog prava koji je usvojen nakon stupanja na snagu Lisabonskog ugovora, Direktivu 2010/64/EU o pravu na tumačenje i prevođenje u kaznenim postupcima. ${ }^{5}$ Direktiva 2010/64 trebala je olakšati primjenu prava na tumačenje i prevođenje uključenog u čl. 6. EKLJP-a za osobe koje ne govore ili ne razumiju jezik na kojem se postupak vodi (Uvodna izjava 14 Direktive 2016/64). Prava predviđena Direktivom trebala bi se

** Ovaj rad izrađen je u okviru projekta "Pravni aspekti digitalne transformacije društva” financiranog od strane Sveučilišta u Rijeci, uniri-drustv-18-252.

1 O interakciji Europskog suda za zaštitu ljudskih prava i Suda Europske unije u području ljudskih prava vidi Crnić-Grotić, V.; Sgardelli Car, N., Ljudska prava u Europskoj uniji u praksi Europskog suda u Luksemburgu, Zbornik Pravnog fakulteta u Zagrebu, vol. 60, br. 5, 2010., str. $971-994$.

2 Ivičević Karas, E.; Burić, Z.; Bonačić, M., Unapređenje procesnih prava osumnjičenika $i$ okrivljenika u kaznenom postupku: pogled kroz prizmu europskih pravnih standarda, Hrvatski ljetopis za kaznene znanosti i praksu, vol. 23, br. 1, 2016., str. 11 - 58, 14.

3 Brussels, 19. 2. 2003., COM (2003) 75 final, str. 4.

4 Ugovor o funkcioniranju Europske unije (pročišćena inačica 2016.), Službeni list C 202 od 7. lipnja 2016.

5 Direktiva 2010/64/EU Europskog parlamenta i Vijeća od 20. listopada 2010. o pravu na tumačenje i prevođenje u kaznenim postupcima, Službeni list L 280 od 26. 10. 2010., str. 1 - 7. Ova je Direktiva usvojena na temelju Putokaza za jačanje postupovnih prava osumnjičenika i okrivljenika u kaznenom postupku iz studenog 2009. s ciljem usklađivanja minimalnih pravila vezanih uz prava osumnjičenika i optuženika u kaznenom postupku: među njima i Direktiva o pravu na informaciju, odnosno Direktiva 2012/13/EU Europskog parlamenta i Vijeća od 22. svibnja 2012. o pravu na informiranje $\mathrm{u}$ kaznenom postupku. 
primjenjivati i prilikom izvršenja Europskoga uhidbenog naloga. ${ }^{6}$ Iako je u ovom radu naglasak na pravima osumnjičenika i okrivljenika u kaznenim postupcima, treba napomenuti da se pitanje jezika i prava na tumačenje i prevođenje sve češće promatra u širem kontekstu, primjerice, ugroženih jezičnih skupina - azilanata, migranata, izbjeglica ili zatvorenika te njihove jezične izolacije u uvjetima $u$ kojima ne mogu govoriti svojim jezikom. ${ }^{7}$

Bez obzira na to što donošenje Direktive svakako čini iskorak u smjeru osnaživanja prava osumnjičenika i okrivljenika koji ne razumiju jezik postupka jer državama članicama pruža dodatnu pomoć u implementaciji standarda zaštite temeljnih ljudskih prava, Liese Katschinka, bivša predsjednica Europskog udruženja pravnih prevoditelja (EULITA), s pravom upozorava da Unijin ambiciozan cilj “olakšavanja pružanja jezične pomoći osumnjičenicima, okrivljenicima, svjedocima i žrtvama koji ne vladaju jezikom suda još je daleko od stvarnosti". ${ }^{8}$ Odredbe Direktive, poput standarda EKLJP-a, državama ostavljaju marginu prosudbe u načinu i razini implementiranja zajamčenih prava. Zbog toga, države, a osobito domaći sudovi imaju veliku odgovornost da osiguraju poštovanje minimalnih prava predviđenih Direktivom, pri čemu im sudska praksa ESLJP-a i Suda EU-a pokazuje put. Naime, presude ESLJP-a ne služe samo da se riješe konkretni predmeti, već široj svrsi obrazlaganja, očuvanja i razvijanja pravila Konvencije. ${ }^{9}$ S druge strane, motiv u pozadini većine presuda Suda EU-a upravo je djelotvornost europskog prava. ${ }^{10}$ Tumačeći konkretne odredbe Direktive, odnosno Konvencije, (škrta) sudska praksa ovih sudova nit je vodilja za sve domaće sudove, a izvjesno je i snažnije buduće međudjelovanje ovih sudova u kontekstu prava na tumačenje i prevođenje okrivljenika. U nastavku stoga slijedi raščlamba recentnih presuda ESLJP-a i Suda EU-a u kojima se oni pozivaju na i tumače Direktivu o pravu na tumačenje i prevođenje.

6 Okvirna odluka Vijeća 2002/584/PUP od 13. lipnja 2002. o Europskom uhidbenom nalogu i postupcima predaje između država članica (Službeni list L 190, 18. 7. 2002., str. 1).

7 Recentna istraživanja utvrdila su znatne razlike u uvjetima služenja kazne zatvorenika i njihovih jezičnih prava. Spencer, D., Overview of Language Rights in the International Criminal Law Sentencing Models, International Journal for the Semiotics of Law, 2018., str. 1 - 18, dostupno na: https://doi.org/10.1007/s11196-018-9544-2 (3. listopada 2018.).

8 Dostupno na: http://www.nrpsi.org.uk/downloads/EULITA_Deadline_for_EU_Directive_transposition_expired.pdf (4. listopada 2018.).

9 Kao što je ESLJP utvrdio u predmetu Irska protiv Ujedinjene Kraljevine, zahtjev br. 5310/71, presuda od 18. siječnja 1978., par. 154.

10 Ćapeta, T., Interpretativni učinak europskog prava u članstvu i prije članstva u EU, Zbornik Pravnog fakulteta u Zagrebu, vol. 56, br. 5, 2006., str. 1443 - 1494, 1467. 


\section{RECENTNA PRAKSA EUROPSKOG SUDA ZA LJUDSKA PRAVA: PREDMET VIZGIRDA PROTIV SLOVENIJE}

Premda je predmet Vizgirda protiv Slovenije ${ }^{11}$ prethodio donošenju i stupanju na snagu Direktive o pravu na tumačenje i prevođenje, štoviše i pristupanju Slovenije EU-u, ESLJP u presudi naglašava kako je utvrđivanje potrebe tumačenja okrivljeniku kako bi se osiguralo pravično suđenje prepoznato usvajanjem te Direktive. Također, neizravno daje i određene upute o tumačenju odredaba Direktive 2010/64, koje mogu biti korisne državama članicama u postupanju s osumnjičenicima i okrivljenicima koji ne razumiju jezik postupka zbog čega je presuda u ovom predmetu osobito zanimljiva iz perspektive ovog rada.

Podnositelj zahtjeva Danas Vizgirda, litavski državljanin, uhićen je u Sloveniji u ožujku 2002. zbog sumnje da je sudjelovao u razbojništvu s troje drugih litavskih državljana te je optužen optužnicom u svibnju 2002. zbog kaznenih djela razbojništva, pljačke te pokušaja kaznenog djela krađe motornog vozila. Prilikom uhićenja podnositelj zahtjeva obaviješten je na ruskom jeziku o razlozima uhićenja, o pravu na šutnju, pravu na branitelja i pravu da obavijesti članove obitelji o uhićenju. ${ }^{12}$ Podnositelju, koji pritom nije zatražio branitelja, tumačio je tumač za ruski jezik. U svim fazama postupka, uključujući i komunikaciju s braniteljem koji mu je dodijeljen po službenoj dužnosti, podnositelju zahtjeva tumačeno je na ruski te su mu i iskazi svjedoka bili prevedeni na ruski. U srpnju 2002. osuđen je na zatvorsku kaznu u trajanju od osam godina i četiri mjeseca. Žalba na tu presudu je odbijena. U veljači 2003. podnositelj zahtjeva podnio je pritužbu navodeći da ne razumije dobro ruski, da je prvostupanjski sud zanemario njegov iskaz u kojem je to tvrdio te da je povrijeđeno njegovo pravo na uporabu vlastitoga jezika u kaznenom postupku naslovljenu “žalba Vrhovnom sudu” Okružnom sudu u Kranju. Žalbom koju je napisao na litavskome jeziku, odnosno uvodno objašnjenje na slovenskome, podnositelj je obavijestio sud kako ne govori ni ruski ni slovenski te da samo malo razumije ruski, no ne može pisati na ruskome jeziku. Ostatak žalbe bile su pritužbe o ocjeni dokaza nižih sudova. Također je naveo kako nije razumio razloge uhićenja, a prilikom suđenja izjavio je da ruski jezik ne razumije dobro. No, bez obzira na to, Okružni sud u Kranju nije imenovao tumača za litavski (par. 37), već je naredio da se žalba prevede na ruski s obzirom na to što se podnositelj njime služio u kaznenom postupku kao i u komunikaciji sa svojim braniteljem (par. 38). Iz odluke Ustavnog suda od 24. ožujka 2005. proizlazi da je Sud u

11 Predmet Vizgirda protiv Slovenije, zahtjev br. 59868/08, presuda od 28. kolovoza 2018.

12 Ibid., par. 11. 
Kranju prethodno utvrdio kako u Sloveniji nema registriranih tumača za litavski zbog čega bi trebalo tražiti pomoć najbližeg Veleposlanstva Litve (par. 38). Kako podnositelj nije odgovorio na zahtjev Suda da preda žalbu na ruskome, Okružni sud njegovu je žalbu odbacio kao nerazumljivu. Navedena odluka prevedena je na ruski i dostavljena podnositelju. Djelujući po ustavnoj tužbi protiv te odluke, Ustavni sud Republike Slovenije okolnosti predmeta ocijenio je izvanrednima. Obrazloženje Okružnog suda u Kranju o tome da se podnositelj tijekom kaznenog postupka služio ruskim pa treba očekivati da na istom jeziku podnese i pisane podneske, nije prihvatio napomenuvši da pisana komunikacija podrazumijeva višu razinu jezične kompetencije (par. 4l) te je ustanovio povredu prava na uporabu vlastitoga jezika u postupku u skladu s čl. 8. Zakona o kaznenom postupku i člankom 62. Ustava ${ }^{13}$ i ukinuo Odluku Okružnog suda u Kranju, upućujući zahtjev za zaštitu zakonitosti na ponovno razmatranje. U ponovljenom postupku, Sud u Kranju ishodio je slovenski prijevod zahtjeva te ga uputio Vrhovnom sudu, koji ga je odbio kao neosnovan. Podnositelj se žalio i na tu odluku, podnijevši ustavnu tužbu protiv presude Vrhovnog suda, koju je Ustavni sud 3. srpnja 2008. odbio (par. 46). ${ }^{14}$

ESLJP je podnositeljev zahtjev u kojem je prigovorio na povredu članka 6. st. l. i 3. EKLJP-a ${ }^{15}$ prihvatio kao osnovan i dopušten na temelju uvjeta dopuštenosti u smislu čl. 35. st. 3. (a) EKLJP-a. Sud je zatim razmotrio navode podnositelja zahtjeva (par. 67 - 69) te Vlade Republike Slovenije (par. 70 - 71), kao i treće stranke Fair Trials International (par. 72 - 74). Podnositelj je naveo kako mu je u postupku trebala biti omogućena upotreba litavskog kao njegova materinskog jezika te da je njegovo poznavanje ruskoga zapravo slabo i da nije razumio prijevod dokumenata na ruski jer nije mogao čitati na ruskome jeziku. Naveo je kako tijekom postupka nije istražena razina njegova poznavanja ruskog te da je Vlada trebala obrazložiti na temelju čega je pretpostavila da podnositelj govori

13 Mjerodavno domaće pravo: Zakon o kaznenom postupku, čl. 4., 7., 8. i 371. Službeni list br. 63/1994; Ustav Republike Slovenije, čl. 29. i 62. Ibid., par. 46.

14 Ustavni sud je utvrdio kako je Vrhovni sud uspio pokazati da je podnositelj dovoljno razumio ruski jezik u svrhu pravičnog suđenja. Također, u ustavnoj tužbi nije bilo pritužbe o tome da nije bio informiran o pravu na uporabu vlastitoga jezika (par. 46). Osim toga, pritužba o tome da su neki dokazi bili na slovenskome, što ga je onemogućilo u tome da se upozna s njima te se učinkovito brani, nije iscrpljena u postupcima pred nižim sudovima, zbog čega se smatra da nije iscrpio pravne lijekove u tom pogledu (par. 46).

15 Europska konvencija za zaštitu ljudskih prava i temeljnih sloboda, Narodne novine, Međunarodni ugovori, br. 18/1997, 6/1999, 14/2002, 13/2003, 9/2005, 1/2006, 2/2010. Čl. 6. st. 3. t. e) Svatko optužen za kazneno djelo ima pravo na besplatnu pomoć tumača ako ne razumije ili ne govori jezik koji se upotrebljava u sudu. 
ruski, jezik koji je i u govoru, a osobito u pisanom obliku, različit od litavskoga. Također je rekao kako nikad nije učio ruski (par. 67). Osim toga, tijekom suđenja nekoliko puta pritužio se da ima poteškoća u razumijevanju jezika na kojem se govorilo, međutim, kako se pritužio na litavskom, nitko ga nije razumio (par. 69). Premda je potpisao zapisnik suđenja, podnositelj zahtjeva ustraje u tvrdnji kako nije znao što potpisuje (par. 68).

Vlada Republike Slovenije tvrdila je kako ni podnositelj zahtjeva, ni njegov branitelj, nisu prigovorili imenovanju tumača za ruski tijekom istražnih radnji, na raspravama ili tijekom žalbenog postupka, odnosno da se pitanje jezika postavilo tek nakon pravomoćnosti presude u ustavnoj tužbi (par. 70). Podnositeljevo poznavanje ruskoga Vlada je ocijenila primjerenim, navodeći da je do samostalnosti Litve 1990. ruski bio službeni jezik u toj zemlji te da je podnositelj, koji je rođen 1980., sigurno učio ruski u školi. Također, suoptuženik A. V. iskazao je kako su on i podnositelj razgovarali na ruskom. Štoviše, tijekom postupka podnositelj je ispitivao svjedoke i odgovarao na pitanja na ruskom te nije prigovorio da ne govori ruski, osim na jednoj raspravi 11. srpnja 2002., kada je zatražio pojašnjenje prijevoda (par. 71).

Sud je naveo opća načela u vezi s čl. 6. st. 3. t. a) i e) EKLJP-a naglašavajući kako svatko optužen za kazneno djelo ima pravo da u najkraćem roku bude obaviješten, potanko i na jeziku koji razumije, o prirodi i razlozima optužbe koja se podiže protiv njega te je posebnu pažnju posvetio sljedećim aspektima: procjeni potrebe tumačenja i obavještavanja o pravu na tumačenje. ${ }^{16}$ Unatoč tomu što navedena odredba Konvencije ne navodi koji se dokumenti trebaju prevesti, Sud smatra da osobito treba voditi računa o optužnici kao formalnom optužnom aktu kojim se pokreće sudski dio kaznenog postupka. Podsjetimo, u predmetu Hermi protiv Italije 2006. godine Sud je utvrdio da je okrivljenik koji nije upoznat s jezikom koji upotrebljava sud u nepovoljnijem položaju ako se optužnica ne prevede na jezik koji razumije, iako to ne uvjetuje nužnost pisanog

16 U skladu s ustaljenom sudskom praksom od Ibrahim $i$ drugi protiv Ujedinjene Kraljevine, zahtjev br. 50541/08 i drugi, presuda od 13. rujna 2016., par. 272, Dvorski protiv Hrvatske, zahtjev br. 25703/11, presuda od 20. listopada 2015., par. 101, 2015. potrebno je u svrhu učinkovitog ostvarenja prava obrane okrivljenika obavijestiti o pravima - ovdje o pravu na tumačenje - na jeziku koji razumije (par. 86 - 87). Bitno je napomenuti da u skladu s Direktivom 2012/13 o pravu na informiranje u kaznenom postupku na koju se Sud pozvao države članice dužne su osumnjičenike i okrivljenike žurno informirati o pravu na branitelja, pravu na besplatnu pravnu pomoć, pravu da budu obaviješteni o optužbi te pravu na tumačenje i prevođenje, i pravu na šutnju usmeno ili pisano. Osim toga, ova opća pouka o pravima mora se dati jednostavnim i razumljivim jezikom. Vidi Ivičević Karas et al., op. cit. u bilj. 2, str. 26. 
prijevoda, ako se okrivljeniku pruži dovoljno informacija usmenim putem (usp. Husain protiv Italije). ${ }^{17}$ Međutim, to ne implicira da prema Konvenciji postoji obveza prevođenja cjelokupnog spisa predmeta (Kamasinski protiv Austrije). ${ }^{18} \mathrm{~S}$ druge strane, čl. 3. st. l. i 2. Direktive 2010/64 propisuje se prijevod tzv. bitnih dokumenata u koje se ubrajaju sve odluke o lišavanju slobode, svaki optužni prijedlog, optužnica te sve presude. No, upravo ta odredba o bitnim dokumentima pokazala se kao nedovoljno jasna iz perspektive nacionalnih sudova te je dala povod za tumačenje Suda EU-a, kao što ćemo vidjeti.

U vezi s pravom na besplatnu pomoć tumača ako osoba ne razumije ili ne govori jezik koji se upotrebljava u sudu (čl. 6. st. 3. t. e EKLJP-a) Sud je ponovio kako se to pravo proteže i na prethodni postupak (par. 76). ${ }^{19}$ Ukratko, tumačenje mora omogućiti okrivljeniku da razumije predmet koji se vodi protiv njega te da se može braniti na način da može predočiti svoju verziju događaja (usp. Güngor protiv Njemačke). ${ }^{20}$ Ono što je bitno iz perspektive država članica jest da obveza nadležnih tijela nije ograničena na imenovanje tumača, već s obzirom na okolnosti predmeta može uključiti i provjeru te praćenje adekvatnosti tumačenja, na što se poziva i Direktiva 2010/64. ${ }^{21} \mathrm{U}$ tu svrhu snimanje npr. policijskog ispitivanja i sudskog postupka čini se nužnim. I ESLJP je prigovorio kako Slovenija nije imala nikakve dokaze o ispitivanju podnositelja kako bi se utvrdila razina njegova poznavanja ruskog u govoru (par. 94). Sud je smatrao kako se manjak suradnje tijekom policijskog ispitivanja te ispitivanja pred istražnim sucem može pripisati teškoćama izražavanja na ruskom te razumijevanja ruskog jezika.

Sud se osvrnuo i na razloge neimenovanje tumača za litavski jezik. Naime, tek nakon drugostupanjske presude Okružni sud u Kranju raspitivao se o dostupnosti tumača za litavski te ustanovio kako u Sloveniji u to vrijeme nije

17 Hermi protiv Italije, zahtjev br. 18114/02, presuda od 18. listopada 2006., par. 68; Husain protiv Italije, zahtjev br. 18913/03, odluka od 24. veljače 2005.

18 Kamasinski protiv Austrije, zahtjev br. 9783/82, presuda od 19. prosinca 1989., par. 74. Upravo na ovu presudu poziva se i Sud EU-a u predmetu Covaci u kojem je prvi put tumačio odredbe Direktive 2010/64. Predmet C-216/14, Kazneni postupak protiv Gavrila Covacija, presuda od 15. listopada 2015., EU:C:2015:686, par. 39.

19 Sukladno čl. 1. st. 2. Direktive 2010/64 pravo na tumačenje i prevođenje u okviru kaznenog postupka primjenjuje se od trenutka kada su osobe obaviještene da su osumnjičene ili optužene za počinjenje kaznenog djela pa do zaključenja postupka, uključujući i izricanje presude te rješenje svih žalbi.

20 Güngor protiv Njemačke, zahtjev br. 31540/96, odluka od 17. svibnja 2001.

21 Prema Uvodnoj izjavi 24 Direktive države članice trebale bi omogućiti provođenje nadzora adekvatnosti ponuđenog tumačenja i prevođenja kad su nadležna tijela u konkretnom slučaju na to upozorena. 
bilo registriranih sudskih tumača za taj jezik, pa bi u tu svrhu bilo potrebno zatražiti pomoć najbližeg litavskog veleposlanstva. S druge strane, kasnije u postupku pred Vrhovnim sudom ishodio se prijevod s litavskog na slovenski i sa slovenskog na litavski (par. 88). Budući da Vlada Republike Slovenije nije tvrdila da su postojali tzv. vrlo uvjerljivi razlozi koji su sprječavali imenovanje tumača za litavski, već je imenovan tumač za ruski jezik na temelju pretpostavke da podnositelj zahtjeva govori ruski, Sud je ključnim pitanjem smatrao je li podnositelju pruženo tumačenje na jeziku kojim je dovoljno dobro vladao u svrhu svoje obrane te, ako nije, je li to potkopalo pravičnost postupka u cjelini (par. 89 - 90).

Sud je utvrdio da nadležna tijela uopće nisu sumnjala u to da podnositelj, litavski državljanin, koji je stigao u Sloveniju kratko prije uhićenja, nije razumio jezik postupka, odnosno slovenski. Nakon privođenja policija ga je obavijestila o razlozima uhićenja i pravu na branitelja uz pomoć tumača za ruski jezik, koji je bio prisutan i prilikom ispitivanja pred istražnim sucem te tijekom sudskog postupka, kao i u komunikaciji s braniteljem. Osim toga, bitni dokumenti prevedeni su mu na ruski. Sud, međutim, nije utvrdio (na temelju zapisnika istrage i postupka) da se podnositelja pitalo razumije li tumačenje i pisani prijevod na ruski u dovoljnoj mjeri za ostvarenje učinkovite obrane na tom jeziku (par. 91). Sud nije prihvatio navode Vlade Republike Slovenije kako se može pretpostaviti da netko govori ruski zato što je litavski državljanin, odnosno da se ruski općenito govori u Litvi (par. 92). Vlada nije potkrijepila svoje navode drugim objašnjenjima te je Sud zaključio da nadležna tijela nisu eksplicitno utvrdila podnositeljevu jezičnu kompetenciju na ruskom, što je ključan element za procjenu o učinkovitom ostvarenju prava zajamčenih čl. 6. st. 6. t. a) i e) EKLJP-a, koja nalažu da se okrivljeniku pruži tumačenje na jeziku koji dovoljno razumije radi osiguranja pravičnosti postupka (par. 93, 97). Bitno je napomenuti kako nadležna tijela nisu u skladu s domaćim postupovnim pravom obavijestila podnositelja o pravu na tumačenje na vlastitom jeziku, niti je Vlada ponudila objašnjenje za taj propust (par. 99). Bez obzira na to što ni podnositeljev pravni zastupnik nije prigovorio u tom smislu, domaći sudovi imaju ulogu ultimativnih čuvara pravičnosti postupka (par. 101).

Uzimajući u obzir sve navedeno, Sud je odlučio da nije dokazano kako je podnositelju pružena jezična pomoć omogućila aktivno sudjelovanje u suđenju protiv njega, što je dovoljan razlog da se suđenje u cjelini smatra nepoštenim (par. 102). U tom smislu Sud je utvrdio povredu čl. 6. st. 1. i 3. Konvencije (par. 103). Podnositelju je dosuđena naknada neimovinske štete u iznosu od 6400 eura te 2500 eura za troškove postupka. 


\subsection{Smjernice za buduće postupanje domaćih sudova u sličnim predmetima}

Presuda ESLJP-a u predmetu Vizgirda protiv Slovenije naznačuje prijelomnost trenutka za pitanje ostvarivanja prava na tumačenje i prevođenje u kaznenim postupcima radi osiguranja prava na pravično suđenje. Naime, ovom presudom Sud nedvosmisleno poručuje da države moraju eksplicitno utvrditi razinu poznavanja jezika na koji se tumači, a koji na temelju EKLJP-a i Direktive 2010/64 ne mora biti materinski jezik okrivljenika. Međutim, kako to države trebaju učiniti, nije jednako jasno. Na temelju čl. 4. Direktive 2010/64 države članice osiguravaju uvođenje postupka ili mehanizma kojim se utvrđuje govore li ili razumiju li osumnjičenici ili optuženici jezik kaznenog postupka i treba li im pomoć tumača. Na državama je da odaberu način na koji će to provoditi, no smatramo da bi pravosudnim tijelima u tome pomogle dodatne upute koje bi omogućile ujednačenije postupanje u pogledu zaštite prava okrivljenika.

I dok je u ranijim predmetima Sud odbacio slične pritužbe s obzirom na to da podnositelji zahtjeva nisu postavili pitanje jezika tijekom postupka i nisu prigovorili zapisniku ${ }^{22}$, odnosno nisu prigovorili na kvalitetu tumačenja za vrijeme suđenja prvostupanjskom ili drugostupanjskom sudu ${ }^{23}$, ovom presudom poručuje da sjeme sumnje treba tražiti dublje. Nacionalni sudovi moraju voditi računa o imenovanju tumača ne samo kada je strani okrivljenik to zatražio, već uvijek kada postoji sumnja da okrivljenik ne vlada dovoljno jezikom, kao u slučaju trećeg jezika. Tada je potrebno utvrditi okrivljenikovo poznavanje trećeg jezika prije donošenja odluke o tumačenju na treći jezik. Okolnosti koje pobuđuju takvu sumnju mogu biti da okrivljenik nije državljanin ili rezident države u kojoj se vodi postupak (par. 81). Osim toga, odluka o tome vlada li okrivljenik dovoljno dobro jezikom postupka ne može se temeljiti na pretpostavkama, već na dokazima (par. 97). Činjenica da je podnositelj tijekom saslušanja na ruskom dao nekoliko jednostavnih izjava nije dovoljna kako bi se utvrdilo da on može učinkovito ostvariti svoju obranu na tom jeziku (par. 95). Slijedom toga, Sud je utvrdio kako razina njegova poznavanja ruskog nije dovoljna za osiguravanje pravičnog postupka (par. 97).

${ }^{22}$ Kao što su argumentirali suci Kucsko-Stadlmayer i Bošnjak u zajedničkom izdvojenom mišljenju pozivajući se na predmete Berisha i Haljiti protiv Bivše Jugoslavenske Republike Makedonije, zahtjev br. 18670/03, odluka od 16. lipnja 2005.; Hacioglu protiv Rumunjske, zahtjev br. 2573/03, presuda od 11. siječnja 2011.; Husain protiv Italije, op. cit. u bilj. 16. Predmet Vizgirda protiv Slovenije, op. cit. u bilj. 11, par. 80. Uçak protiv Ujedinjene Kraljevine, zahtjev br. 44234/98, odluka od 24. siječnja 2002. 
S obzirom na to što, kako je uvodno naznačeno, ni EKLJP, ni Direktiva 2010/64 ne daju konkretne upute o tome kako domaći sudovi trebaju utvrditi potrebu za tumačenjem, ovom presudom Sud ipak daje neke upute za postupanje država, odnosno sudova, kao primjerice da se u tu svrhu upotrebljavaju pitanja otvorenog tipa (par. 84). Kako navodi treća stranka Fair Trials International ${ }^{24}$, u kontekstu upotrebe trećeg jezika nadležna tijela moraju moći utvrditi da okrivljenik ima dovoljno znanje jezika na koji se tumači uzimajući u obzir elemente kao što su razina poznavanja jezika, pismenost, osobna situacija te složenost konkretnog predmeta (par. 72). Da se iščitati i nužnost promatranja ovoga pitanja u širem kontekstu. Drugim riječima, pri ocjeni pravičnosti suđenja u cjelini navode da treba uzeti u obzir i korištenje dokaza pribavljenih neadekvatnim tumačenjem i učinka takvog tumačenja na ostvarenje drugih prava obrane. Sud bi trebao zaključiti kako se obrana mogla voditi drukčije da je bilo pruženo odgovarajuće tumačenje te utvrditi povredu čl. 6. (par. 74). Nadalje, kako bi pravo zajamčeno čl. 6. st. 3. e) EKLJP-a bilo praktično i učinkovito, nadležna tijela imaju obvezu ne samo imenovati tumača, već i, ako su upozoreni u određenim okolnostima, nadzirati te provjeriti adekvatnost pruženog tumačenja.

\section{RECENTNA PRAKSA SUDA EUROPSKE UNIJE}

Dodatne upute o postupanju s okrivljenicima koji ne razumiju jezik postupka daje i Sud EU-a koji je od 2014. u tri predmeta bio pozvan tumačiti odredbe Direktive 2010/64.

\subsection{Predmet C-216/14 Covaci ${ }^{25}$}

Policijskom kontrolom 25. siječnja 2014. utvrđeno je da je rumunjski državljanin G. Covaci na području Savezne Republike Njemačke upravljao vozilom bez valjanog ugovora o obveznom osiguranju od automobilske odgovornosti i da je potvrda o osiguranju koju je pokazao bila krivotvorena. Nakon toga ga je o tim činjenicama saslušala policija uz pomoć tumača. Budući da G. Covaci nije imao ni prebivalište ni boravište na području primjene njemačkog zakona, u pisanom je obliku neopozivo opunomoćio tri službenika općinskog suda u Laufenu (Amtsgericht Laufen) za primanje pismena. Nakon provedene istrage Državno

24 Fair Trials International kao treća stranka u postupku u skladu s odredbama čl. 36. st. 1., 2. i 3. Konvencije.

25 Predmet C-216/14, Kazneni postupak protiv Gavrila Covacija, presuda od 15. listopada 2015., EU:C:2015:686. 
odvjetništvo u Traunsteinu 18. ožujka 2014. od suda je zatražilo izdavanje kaznenog naloga protiv G. Covacija za sva kaznena djela koja je počinio u svrhu izricanja novčane kazne. ${ }^{26}$ Državno odvjetništvo u Traunsteinu zatražilo je da se kazneni nalog dostavi posredstvom punomoćnika i da se eventualna pravna sredstva protiv naloga sastave na njemačkom jeziku. ${ }^{27}$ Sudu su bila upućena dva prethodna pitanja koja su se ticala Direktive 2010/64 o pravu na tumačenje i prevođenje i Direktive 2012/13 o pravu na informiranje u kaznenim postupcima. Mi ćemo se ovdje baviti samo pitanjem u pogledu Direktive 2010/64. Konkretno, općinski sud u Laufenu (Amtsgericht Laufen) iz Njemačke postavio je pitanje treba li čl. l. st. 2. i čl. 2. st. 1. i st. 8. Direktive tumačiti na način da se oni protive sudskom nalogu kojim se na temelju članka 184. Zakona o ustrojstvu sudova Savezne Republike Njemačke od okrivljenika zahtijeva da pravna sredstva podnose isključivo na jeziku suda kako bi ta sredstva bila dopuštena. Prema čl. 1. st. 2. Direktive pravo na tumačenje i prevođenje primjenjuje se od trenutka kad nadležno tijelo neke države članice službenom obaviješću ili na neki drugi način obavijesti osobe da su osumnjičene ili optužene za počinjenje kaznenog djela, pa do zaključenja postupka (dok se konačno ne utvrdi jesu li počinili to kazneno djelo, uključujući, prema potrebi, i izricanje presude i rješenje svih žalbi). Na temelju čl. 2. st. 1. Direktive države osiguravaju da se osumnjičenicima ili optuženicima koji ne govore ili ne razumiju jezik predmetnog kaznenog postupka bez odgode omogući tumačenje tijekom kaznenog postupka pred istražnim i pravosudnim tijelima, uključujući tijekom policijskih ispitivanja, svih sudskih rasprava i svih drugih potrebnih saslušanja.

\subsubsection{Dva kolosijeka prava na jezičnu pomoć i nužnost širokog tumačenja minimalnih pravila}

U kontekstu ovoga predmeta bitno je istaknuti kako je pravo na jezičnu pomoć u Direktivi 2010/64 razdvojeno na dva dopunska prava: pravo na tumačenje uređeno člankom 2. i pravo na prijevod bitnih dokumenata uređeno člankom 3., pri čemu države članice moraju osigurati da je tumačenje, odnosno prevođenje dostatne kvalitete da jamči pravičnost postupka (čl. 2. st. 8., čl. 3. st. 9, čl. 5.). Kao što je poznato, direktive, za razliku od uredaba, preuzimaju se

26 Riječ je o pojednostavnjenom kaznenom postupku koji omogućuje određivanje kazne na jednostran način, bez održavanja rasprave. Svojstvo pravomoćne presude stječe istekom roka od dva tjedna od dostave navedenog naloga (ovdje punomoćnicima optuženika). Prigovor, koji može biti podnesen pisano ili usmeno tajništvu suda, dovodi do održavanja sudske rasprave. Ibid., par. 20.

Ibid., par. 21. 
u nacionalno zakonodavstvo u pogledu cilja koji treba ostvariti, odnosno ovdje poštovanja minimalnih pravila. ${ }^{28}$ Pritom, države članice imaju izbor kako će to ostvariti. Tako i Direktiva 2010/64 ostavlja državama članicama marginu prosudbe vezano uz izbor oblika, primjerice, tumačenja ${ }^{29}$ pod uvjetom da je ono besplatno i dovoljno kvalitetno da pruža zaštitu postupovne pravičnosti i da obrani omogućava izvršavanje njezinih prava. Činjenica da se navedeni pravni standardi nazivaju minimalnim pravilima ne znači da su to manje važna pravila, već je riječ o, kako to ističe nezavisni odvjetnik Bot, "pravilima od kojih nije moguće odstupiti” ${ }^{30}$ Budući da ne postoji jedinstveni postupovni sustav $u$ EU-u, iznimno je bitno da sve države poštuju ova načela. U tom smislu ona se moraju tumačiti na način da im se osigura potpun djelotvoran učinak, a nipošto smanjivanjem područja tih pravila doslovnim tumačenjem odredaba jer bi to moglo imati za učinak smanjenje uzajamnog priznavanja. ${ }^{31} \mathrm{~S}$ tim na umu, potrebno je odrediti koji od članaka, ovdje 2. ili 3. Direktive može najbolje jamčiti okrivljeniku pravo na djelotvorno ostvarivanje pravnih sredstava. ${ }^{32}$

Prema mišljenju nezavisnog odvjetnika Bota, koje za Sud nije obvezujuće, u konkretnom predmetu ne može se zahtijevati prevođenje na jezik postupka na temelju članka 3. Direktive, koji uređuje prevođenje bitnih dokumenata s jezika postupka na jezik koji razumije okrivljenik. ${ }^{33}$ Iako popis bitnih doku-

28 Čl. 288. UFEU-a, op. cit. u bilj. 4.

29 Čl. 2. st. 6. Direktive predviđa uporabu komunikacijskih tehnologija kada nazočnost tumača nije moguća; a čl. 3. st. 7. i usmeni prijevod ili usmeni sažetak bitnih dokumenata kao iznimku od općih pravila iz st. 1., 2., 3. i 6., pod uvjetom da se takvim usmenim prijevodom ili usmenim sažetkom ne dovodi u pitanje pravičnost postupka.

30 Mišljenje nezavisnog odvjetnika Yvesa Bota od 7. svibnja 2015. Predmet C-216/14, Kazneni postupak protiv Gavrila Covacija, ECLI:EU:C:2015:305, par. 32.

31 Ibid., par. 74. Direktive donesene na temelju članka 82. Ugovora o funkcioniranju EU-a moraju se tumačiti s obzirom na ciljeve područja slobode, sigurnosti i pravde, i osobito one pravosudne suradnje u kaznenim stvarima. Važnost širokog tumačenja Direktive 2010/64 naglašena je u Uvodnoj izjavi 32: "Ovom Direktivom trebalo bi propisati minimalna pravila. Države članice trebale bi imati mogućnost proširiti prava utvrđena ovom Direktivom kako bi osigurale višu razinu zaštite i u situacijama kojima se ova Direktiva ne bavi. Razina zaštite ne bi nikad trebala biti niža od standarda predviđenih u EKLJP-u ili Povelji kako ih se tumači u sudskoj praksi Europskoga suda za ljudska prava ili Suda Europske unije."

32 "Cilj djelotvornije pravosudne suradnje u kaznenim stvarima, koji se postiže jačanjem postupovnih prava osumnjičenika i okrivljenika u okviru kaznenog postupka, podrazumijeva, naprotiv, široko tumačenje Direktive 2010/64, to jest ono koje osigurava bolju zaštitu prava na obranu dotičnih osoba”. Ibid.

33 Ibid., par. 57. 
menata nije iscrpan, riječ je o dokumentima koje sastavlja nadležno sudsko tijelo te njihovo prevođenje ima za cilj da okrivljenici razumiju djela koja im se stavljaju na teret. ${ }^{34}$ Bot ispravno tumači da razumjeti dokument znači da je riječ o dokumentu koji obrana zaprima, a ne podnosi (poput žalbe na kazneni nalog). Međutim, pravo na jezičnu pomoć ima široku primjenu te obrana može zatražiti besplatne usluge tumača tijekom trajanja cijelog postupka, dakle i u okviru podnošenja žalbe. ${ }^{35}$ Kako bi se osigurala pravičnost postupka svakako je nužno ne samo da okrivljenik razumije, nego također i da ga se razumije. Oslanjajući se na čl. 2. Direktive, koji se bavi pravom na tumačenje, nezavisni odvjetnik Bot ne vidi razlog zašto da se okrivljeniku, koji nema odvjetnika, isključi mogućnost da ima pravo na tumača u pogledu pravnog sredstva protiv kaznenog naloga. ${ }^{36}$ Drugim riječima, smatrao je da je na nadležnom sudu da u skladu s člankom 2. Direktive, odnosno primjenom prava na tumačenje, pribavi sredstva za osiguranje prevođenja pravnog sredstva na jezik postupka. ${ }^{37}$

U odgovoru na navedeno prethodno pitanje Sud EU-a smatrao je da čl. 1 . st. 2. i čl. 2. st. 1. i st. 8. Direktive ne treba tumačiti na način da se oni protive sudskom nalogu kojim se na temelju članka 184. Zakona o ustrojstvu sudova Savezne Republike Njemačke od okrivljenika zahtijeva da pravna sredstva podnose isključivo na jeziku suda, međutim, kako dodaje Sud, pod uvjetom da nadležna tijela ne smatraju da sukladno čl. 3. st. 3. Direktive takav prigovor predstavlja bitan dokument imajući na umu okolnosti predmeta. ${ }^{38}$

\subsection{Predmet C-25/15 Balogh}

Kratko ćemo se osvrnuti i na presudu u predmetu Balogh C-25/1539 koja se tiče područja primjene Direktive 2010/64. Zahtjev Sudu EU-a pokrenut je u okviru postupka priznavanja učinka pravomoćne presude u Mađarskoj koja je donesena u Austriji. Presudom suda u Austriji mađarski državljanin I. Balogh osuđen je na kaznu zatvora od četiri godine i šest mjeseci za tešku krađu i provalu te mu je naloženo plaćanje troškova. Mađarski sud, koji je uputio zahtjev Sudu EU-a, pitao je treba li čl. 1. st. 1. i 2. te čl. 3. st. 1. i 2. Direktive 2010/64

\footnotetext{
34 Ibid., par. 58.

35 Ibid., par. 63.

36 Ibid., par. 67.

37 Ibid., par. 81.

38 Predmet C-216/14, op. cit. u bilj. 25, par. 51.

39 Predmet C-25/15, Kazneni postupak protiv Istvána Balogha, presuda od 9. lipnja 2016., ECLI:EU:C:2016:423.
} 
tumačiti na način da se ne primjenjuju na situaciju kada sud jedne države članice namjerava prevesti presudu koju je donio sud druge države članice na jezik postupka te države u okviru nacionalnog postupka priznavanja učinkovitosti stranih presuda. Nakon što je Sud zatražio pojašnjenje o tome je li Balogh iskoristio pravo predviđeno čl. 3. Direktive 2010/64 na prijevod presude regionalnog suda u Eisenstadtu (Landesgericht Eisenstadt) donesene protiv njega, koja zaista je prevedena na mađarski jezik u usmenom obliku nakon rasprave pred tim sudom, a zatim u pisanom obliku, odgovorio je očekivano da se Direktiva 2010/64 ne odnosi na poseban postupak priznavanja stranih presuda. ${ }^{40} \mathrm{~K}$ tome, mađarska praksa protivna je i čl. 82. st. 1. podstavku 1. UFEU-a prema kojem se pravosudna suradnja u kaznenim stvarima u Uniji temelji na načelu uzajamnog priznavanja presuda i sudskih odluka ${ }^{41}$ te čl. 4. st. 2. i čl. 5. st. 1. Okvirne odluke 2009/315 kao i Odluci 2009/316. ${ }^{42}$ Štoviše, uvođenjem Europskoga informacijskog sustava kaznene evidencije (ECRIS) te upotrebom standardiziranih obrazaca za zahtjeve za pribavljanje izvoda iz kaznenih evidencija dostupne na svim službenim jezicima Unije, nije potreban ni prijevod, ni slanje strane presude. Umjesto provođenja posebnog postupka priznavanja presuda se upisuje u kaznenu evidenciju na temelju obavijesti koju šalje država koja je donijela osuđujuću presudu.

\subsection{Sleutjes C-278/16}

Predmet Sleutjes C-278/16 $6^{43}$ omogućio je Sudu EU-a da utvrdi svoju praksu u vezi s Direktivom 2010/64. Općinski sud u Dürenu (Amtsgericht Düren) 2. studenog 2015. na zahtjev Državnog odvjetništva u Aachenu izdao je kazneni nalog ${ }^{44}$ protiv okrivljenika nizozemskog državljanina F. Sleutjesa. Okrivljenik je

$40 \quad$ Ibid., par. 57.

41 Ibid., par. 54.

42 Okvirna odluka Vijeća 2009/315/PUP od 26. veljače 2009. o organizaciji i sadržaju razmjene informacija izvađenih iz kaznene evidencije između država članica (SL 2009., L 93, str. 23) i Odluka Vijeća 2009/316/PUP od 6. travnja 2009. o uspostavi Europskog informacijskog sustava kaznene evidencije (ECRIS) na temelju članka 11. Okvirne odluke 2009/315/PUP (SL 2009., L 93, str. 33). I prethodno pitanje trebalo je preformulirati da obuhvati tumačenje ovih odluka. Predmet C-25/15, op . cit. u bilj. 39, par. $33-34$.

43 Predmet C-278/16, Kazneni postupak protiv Franka Sleutjesa, presuda od 12. listopada 2017., ECLI:EU:C:2017:757.

44 I u ovom predmetu riječ je o pojednostavnjenom postupku koji ne zahtijeva raspravu. Okrivljenik može imati pravo na kontradiktorno raspravljanje tako da podnese prigovor protiv toga naloga. 
u Nizozemskoj bio kažnjen zbog napuštanja mjesta nesreće s trideset dnevnih iznosa u visini od 30 eura te mu je oduzeta vozačka dozvola. Tijelu nadležnom za izdavanje vozačkih dozvola naloženo je da okrivljeniku zabrani da se i dalje koristi inozemnom vozačkom dozvolom te da mu se ne dodijeli njemačka vozačka dozvola idućih devet mjeseci. Kazneni nalog sadržavao je i uputu o pravnom lijeku, navodeći da će postati pravomoćan ako okrivljenik u roku od dva tjedna od njegove dostave ne podnese prigovor na njemačkome jeziku općinskom sudu u Dürenu 12. studenog 2015. kazneni nalog dostavljen je F. Sleutjesu na njemačkome jeziku; istodobno je dostavljena i uputa o pravnom lijeku u prijevodu na nizozemski. F. Sleutjes je 24. studenoga 2015. porukom elektroničke pošte na nizozemskom jeziku prigovorio kaznenom nalogu te dva dana kasnije poslao upit općinskom sudu u Dürenu o tome je li poruka zaprimljena. Sud ga je dopisom od 1. prosinca, poslanom 8. prosinca 2015., obavijestio da svi podnesci podneseni sudu moraju biti na njemačkome jeziku. Okrivljenikov tadašnji branitelj 1. prosinca 2015. podnio je telefaksom prigovor protiv kaznenog naloga (od 1. studenoga 2015.) te zatražio povrat u prijašnje stanje zbog propuštenog roka za podnošenje prigovora. Odlukom od 28. siječnja 2016. sud je odbacio okrivljenikov prigovor protiv pobijanog kaznenog naloga kao nedopušten (jer je podnesen nepravovremeno) te je odbio prijedlog za povrat u prijašnje stanje ${ }^{45}$ Branitelj je protiv te odluke podnio žalbu povodom koje se pokrenuo postupak pred zemaljskim sudom u Aachenu (Landgericht Aachen) koji je i uputio prethodno pitanje Sudu EU-a, smatrajući da nije posve jasno treba li i kaznene naloge prevesti za optuženike, odnosno: "Treba li članak 3. [Direktive 2010/64] tumačiti na način da pojam 'presuda' u članku 37. stavku 3. Njemačkog kaznenog zakona [StPO-a] također uključuje i kaznene naloge u smislu članka 407. i sljedećih [StPO-a]?"46 Sud je odgovorio da čl. 3. Direktive treba tumačiti na način da akt kao što je nalog predviđen nacionalnim pravom radi sankcioniranja lakših kažnjivih djela i koji je izdao sud u jednostranom pojednostavnjenom postupku predstavlja "bitan dokument" u smislu stavka 1. tog članka. ${ }^{47}$

\section{4. Šira razmatranja presuda Suda EU-a}

Kao što smo vidjeli, nacionalna pravila kojima se osobi ne dopušta da protiv kaznenog naloga na njemačkome podnose prigovor na jeziku koji razumije nisu

45 Predmet C-278/16, op. cit. u bilj. 43, par. 10 - 16.

46 Ibid., par. 19.

47 Ibid., par. 35. 
protivna Direktivi 2010/64. Premda u predmetu Covaci Sud nije bio pozvan odgovoriti na pitanje prijevoda prigovora protiv kaznenog naloga, dodao je da nacionalna tijela mogu to omogućiti ako smatraju da neki dokument predstavlja bitan dokument. No, sudeći po njemačkome sudu koji je uputio prethodno pitanje, očito je da se stajališta nacionalnih sudova razilaze oko prevođenja kaznenih naloga. Općenito, je li razumno zahtijevati da se osiguraju baš sva prava iz Direktive u slučaju prometnih prekršaja? Odredbom čl. 1. st. 3. Direktive 2010/64 upravne kazne za prometne prekršaje nisu uključene u područje primjene Direktive. Prema Uvodnoj izjavi 16. Direktive tipičan je primjer takvih prometnih prekršaja prekoračenje brzine. Ali, ukoliko okolnosti predmeta ne predstavljaju puko prekoračenje brzine, utoliko se na njega primjenjuju prava predviđena Direktivom. ${ }^{48}$ To proizlazi i iz teksta čl. 3. st. 1. koji govori “o svim dokumentima bitnima za osiguranje ostvarivanja njihova prava na obranu i jamstva pravičnosti postupka", dok st. 2. utvrđuje da se u bitne dokumente ubrajaju sve odluke o lišavanju slobode, svaki optužni prijedlog ili optužnica te sve presude.

Svakako treba imati na umu da su navedenom odredbom izdvojeni primjeri bitnih dokumenata, a temeljem čl. 3. st. 3. Direktive 2010/64 "na nadležnim je tijelima da u svakom pojedinačnom predmetu odluče je li bitan još neki dokument", kao što je i Sud naglasio u presudi Covaci. ${ }^{49}$ No, i bez obzira na pojmovnu analizu teksta čl. 3. Direktive 2010/64, vodeći računa o načelu ekvivalentnosti, okrivljenike i osumnjičenike ne smije se staviti u nepovoljniji položaj od nacionalnih državljana. K tome, šira razmatranja cilja Direktive, a to je, podsjećamo, osigurati osumnjičenicima ili optuženicima pravo na tumačenje i prevođenje u kaznenom postupku kako bi im se zajamčilo pravo na pravično suđenje (Uvodna izjava 14), podupiru stajalište da se kazneni nalog, osim u opisanim situacijama prometnih prekršaja, mora priznati kao bitan dokument koji zahtijeva prijevod ako optuženik ne razumije jezik.

48 Usporedi Mišljenje nezavisnog odvjetnika Nilsa Wahla od 11. svibnja 2017. Predmet C-278/16, Kazneni postupak protiv Franka Sleutjesa, ECLI:EU:C:2017:366, par. 32.

49 Zanimljiva je rasprava o tome može li se kazneni nalog izjednačiti s optužnim prijedlogom ili optužnicom, kako tvrdi Komisija, ili s presudom. Svakako ima sličnosti s presudom jer riječ je o odluci koju izdaje sud i koja postaje pravomoćna ako nije podnesen prigovor u propisanom roku. Vidi ibid., par. 30. 


\section{ZAHTJEVI IZ DIREKTIVE 2010/64 ZA DRŽAVE ČLANICE NA PRIMJERU HRVATSKE}

Direktiva 2010/64 o pravu na tumačenje i prevođenje pravovremeno je preuzeta u kazneno zakonodavstvo Republike Hrvatske izmjenom i dopunom niza zakona: Zakonom o kaznenom postupku, Prekršajnim zakonom, Zakonom o sudovima, Zakonom o Pravosudnoj akademiji i Pravilnikom o stalnim sudskim tumačima ${ }^{50}$ Posljednjim izmjenama i dopunama Zakona o kaznenom postupku iz 2017. uklonjena su neka ranija odstupanja od Direktive, koja su dovodila do prijepora u praksi. Primjerice, čl. 3. st. 5. Direktive propisuje pravo žalbe na odluku kojom se utvrđuje da nije potrebno prevesti neke dokumente ili njihove ulomke, što nije bilo preuzeto ranijim novelama Zakona o kaznenom postupku. Zakonom o izmjenama i dopunama Zakona o kaznenom postupku iz 2017. godine u čl. 8. st. 6. dodana je rečenica: "Protiv rješenja kojim se odbija zahtjev okrivljenika da se pisano prevede dokaz ili njegov dio za koji okrivljenik smatra da je nužan za korištenje procesnih prava obrane, okrivljenik ima pravo žalbe".

Nadalje, s obzirom na neka odstupanja od prakse korištenja tumača u ranim fazama kaznenog postupka potrebno je jasnije propisati i osigurati pravo na besplatnu pomoć tumača i onda kada nije riječ o radnji pred tijelom kaznenog postupka. ${ }^{51}$ Ako domaći sud posumnja da okrivljenik u dovoljnoj mjeri ne vlada jezikom suda, osumnjičenik ili okrivljenik ima pravo na besplatnu pomoć tumača te sud daje pouku o pravu korištenja jezika čim postoji vjerojatnost da službeni jezik suda sudionik postupka ne poznaje dovoljno dobro, odnosno, na njegov zahtjev. ${ }^{52}$ Upitno je međutim imaju li sudionici u kaznenom postupku potrebna znanja za procjenu o poznavanju jezika. Osnovna pretpostavka jest da se okrivljenik izjasnio da će koristiti drugi jezik. Istraživanje provedeno među hrvatskim pravosudnim dužnosnicima i policijskim službenicima ${ }^{53}$ pokazuje da se potreba za tumačenjem i prevođenjem utvrđuje tako što okrivljenik izjavi da

50 Zakon o kaznenom postupku, Narodne novine, br. 152/2008, 76/2009, 80/2011, 121/2011, 91/2012, 70/2017; Prekršajni zakon, Narodne novine, br. 107/2007 i 39/2013; Zakon o sudovima, Narodne novine, br. 122/2010, 27/2011 i 130/2011; Zakon o pravosudnoj akademiji, Narodne novine, br. 153/2009 i 127/2010; Pravilnik o stalnim sudskim tumačima, Narodne novine, br. 88/2008. Detaljno o preuzimanju odredaba ove Direktive u: Ivičević Karas et al., op. cit. u bilj. 2, str. 16 - 24.

51 Ivičević Karas, E.; Burić, Z.; Bonačić, M., Prava obrane u različitim stadijima hrvatskog kaznenog postupka: Rezultati istraživanja prakse, Hrvatski ljetopis za kazneno pravo i praksu, vol. 23, br. 2, 2016., str. 509 - 545, 544.

52 Pavišić, B., Komentar Zakona o kaznenom postupku, Templar-book, Šmrika, 2015., str. 39.

53 Ivičević Karas et al., op. cit. u bilj. 51, str. 525. 
ne govori i ne razumije hrvatski jezik. Ispitanici iz redova državnih odvjetnika i policijskih službenika izjavili su kako koriste tumača čak i kad je riječ o državljanima država sa sličnim jezikom. ${ }^{54} \mathrm{~S}$ druge strane, provedeno istraživanje ukazalo je i na neke loše prakse kao što je nuđenje engleskoga kao alternativnog jezika u situacijama kada bi trebalo dugo čekati tumača, odnosno korištenje policijskim službenicima koji govore osumnjičenikov jezik. ${ }^{55}$ Premda ni Direktiva 2010/64 ne određuje da jezik na koji se prevodi osobi koja ne razumije jezik postupka mora biti materinski, odluke o upotrebi nekog drugog jezika ne smiju se donositi proizvoljno. ${ }^{56}$ Opisani slučajevi odnosili su na najranije stadije kaznenog postupka u kojima osumnjičenici nisu bili uhićeni, odnosno tzv. obavijesne razgovore. S obzirom na posljednje izmjene i dopune Zakona o kaznenom postupku iz 2017. i formaliziranje ispitivanja osumnjičenika prema čl. 208. a, izvjesno je da će se i navedene loše prakse iskorijeniti. ${ }^{57}$ Bez obzira na to, u skladu s čl. 6. Direktive države moraju od tijela nadležnih za stručno osposobljavanje sudaca, tužitelja i pravosudnog osoblja uključenog u kazneni postupak zahtijevati da pozornost posvete posebnostima komuniciranja uz pomoć tumača. Kao što smo vidjeli na primjeru predmeta Vizgirda, nadležna tijela moraju biti osobito oprezna kada je riječ o upotrebi trećeg, odnosno nematerinskog jezika (te u svrhu procjene razine poznavanja jezika upotrebljavati pitanja otvorenog tipa; uzeti u obzir razinu pismenosti osobe, osobnu situaciju te složenost konkretnog predmeta; ali prepoznati možebitne skrivene motive osumnjičenika i okrivljenika koji ciljaju odugovlačenju postupka). Od nadležnih tijela nedvojbeno se očekuje visoka razina senzibiliteta za pitanje jezika kako bi ispravno procijenila je li okrivljenikovo poznavanje jezika dovoljno da omogući komunikaciju odnosno ostvarenje djelotvornog prava na obranu. ${ }^{58}$

54 Ivičević Karas et al., ibid., str. 534. Vidi i Odluku i Rješenje Ustavnog suda Republike Hrvatske broj: U-III-6559/2010 od 13. studenoga 2014.

55 Ivičević Karas et al., ibid., str. 525 - 526.

56 Vidi Mišljenje nezavisnog odvjetnika Nilsa Wahla, op. cit. u bilj. 48, par. 40.

57 Zakonom o izmjenama i dopunama Zakona o kaznenom postupku, Narodne novine, br. 145/2013, člankom 208. a), uređeno je da poziv osumnjičeniku sadrži i pouku o pravu na tumačenje i prevođenje. Dakle, osumnjičenici koji se pozivaju na policijsko ispitivanje također moraju biti obaviješteni o pravu na prevođenje i tumačenje.

58 Pitanje je jesu li osobe koje o tome odlučuju dovoljno obučene. Nedovoljna obuka sudionika kaznenog postupka u pogledu prava na tumačenje i prevođenje odražava se i na nekorištenje instituta usmjerenih na ostvarenje ekonomičnosti tumačenja i prevođenja, kao što je upotreba tehnologije, odnosno korištenje usmenog prevođenja dokumenta (vidi Jačanje procesnih prava osumnjičenika i okrivljenika u kaznenom postupku u Hrvatskoj: Preporuke za unapređenje normativnog okvira i prakse, str. 10, dostupno 
Stoga, iako s motrišta europskih pravnih standarda pravo na tumačenje i prevođenje u kaznenim postupcima jest u Hrvatskoj zadovoljavajuće uređeno, stručno usavršavanje i dodatne upute $u$ vidu najboljih praksi ili priručnika za postupanje svakako bi unaprijedili i olakšali ostvarivanje prava na tumačenje i prevođenje u praksi radi osiguranja pravičnosti postupka. Kao što sudska praksa ESLJP-a i Suda EU-a pokazuje, nerijetko je potrebna pomoć u tumačenju opsega pravnih standarda Konvencije i prava EU-a. Upravo zbog toga, a i imajući na umu uočene nedorečenosti Direktive 2010/64, neke su države usvojile dodatne zakone kako bi konkretizirale preuzete odredbe iz Direktive. Radi što učinkovitijeg preuzimanja Direktive o pravu na tumačenje i prevođenje i Direktive o pravu na informiranje, Savezna Republika Njemačka tako je 2013. godine usvojila Zakon o jačanju postupovnih prava okrivljenika u kaznenom postup$\mathrm{ku}^{59}$ Ono što je iznimno važno jest da države članice moraju voditi računa o tome da odredbe Direktive tumače i provode u skladu s pravima EKLJP-a i Povelje, odnosno sudskom praksom ESLJP-a i Suda EU-a. S obzirom na važnost jedinstvene primjena pravnih standarda Konvencije i odredaba Direktive o pravu na tumačenje i prevođenje, trebalo bi razmotriti i usavršavanje svih sudionika kaznenog postupka, pa i sudskih tumača. ${ }^{60}$ Ovdje ćemo ukratko izdvojiti pozitivne prakse koje su u tom smislu usvojile neke države nakon stupanja na snagu Direktive 2010/64. Bez obzira na važnu ulogu tumača u osiguranju pravičnosti postupka, utvrđena su znatna odstupanja u radu i načinu imenovanja tumača, njihova ponovnog imenovanja, obuci te, ne manje važno, u visini nagrade koju ostvaraju za svoj rad u državama članicama. ${ }^{61}$ Posljedica niskih nagrada za tumačenje i prevođenje u pojedinim državama dovela je do toga da sudovi i policija sve teže pronalaze (kvalitetne) sudske tumače, iako ih danas, paradoksalno, zbog slobode kretanja u EU-u i globalnog trenda migracija

na: http://www.hpc.hr/wp-content/uploads/2017/03/\%E2\%80\%9EPreporuke-za-unapre\%C4\%9lenje-normativnog-okvira-i-prakse\%E2\%80\%9C.pdf (1. listopada 2018.)).

59 Gesetz zur Stärkung der Verfahrensrechte von Beschuldigten im Strafverfahren (BeVReStG) od 2. srpnja 2013. (Službeni list I 1938, br. 34), dostupno na: https:// www.buzer.de/gesetz/10743/index.htm (5. listopada 2018.). Vidi i Bajčić, M., The Way Forward for Court Interpreting in Europe, u: Šarčević, S. (ur.), Language and Culture in EU Law: Multidisciplinary Perspectives, Ashgate, Surrey, 2015., str. 219 - 237, 222 223.

Iako čl. 6. Direktive eksplicitno predviđa stručno osposobljavanje (samo) sudaca, tužitelja i pravosudnog osoblja.

${ }^{61}$ Katschinke, L., An ISO Standard for Interpreting Services in Judicial Settings, u: Bajčić, M.; Dobrić Basaneže, K. (ur.), Towards the Professionalization of Legal Translators and Court Interpreters in the EU, Cambridge Scholars Publishing, Newcastle upon Tyne, 2016., str. 14 - 23; Bajčić, op. cit. u bilj. 59. 
sve više trebaju. ${ }^{62}$ Navedeno upućuje na nužnost bolje i ujednačenije regulacije djelatnosti i daljnje profesionalizacije tumača kako bi se osigurala kvaliteta tumačenja i prevođenja te pravičnost postupka. S jedne strane, potrebno je uvesti specijalizirane programe obrazovanja sudskih tumača, u obliku poslijediplomskih studija ili cjeloživotnog učenja. Za razliku od Sjedinjenih Američkih Država i Kanade, Europa oskudijeva u takvim programima. Kao svijetli primjer izdvajamo program "Prevođenje i tumačenje za sudove i javne službe", uveden 2013. godine na Sveučilištu Magdeburg-Stendal u Njemačkoj. ${ }^{63}$ Osmišljen kao cjeloživotno učenje u trajanju od dva semestra, program osposobljava polaznike za rad sudskih tumača te nakon završetka programa dobivaju certifikat koji ih kvalificira da postanu prisegnuti tumači imenovani od Ministarstva Savezne države Saske i Anhalta. Program obuhvaća usavršavanje u interdisciplinarnom području jezika, prava i prevođenja, odnosno tumačenja.

S druge strane, daljnja profesionalizacija tumača ovisi i o radu profesionalnih udruga koje mogu unaprijediti njihov profesionalni status. Premda u Hrvatskoj trenutačno djeluje nekoliko udruga sudskih tumača ${ }^{64}$, u usporedbi s regulacijom djelatnosti sudskih vještaka i procjenitelja očituju se značajne razlike od visine nagrade koja se Pravilnikom o stalnim sudskim vještacima određuje u bodovima i znatno premašuje visinu nagrade sudskih tumača, obveze sklapanja ugovora o osiguranju od odgovornosti za obavljanje poslova stalnog sudskog vještaka, do duljine trajanja obuke te iskustva potrebnog za obavljanje te djelatnosti. ${ }^{65}$ Osim toga, kako bi tumačenje i prevođenje uistinu bilo kvalitetno na način da omogućuje pravičnost postupka, i sudski tumači trebali bi sudjelovati u dodatnim stručnim usavršavanjima, poput ostalih sudionika kaznenog postupka u

62 O tome svjedoči članak Dolmetscher: Bablyon im Gericht, Die Zeit, 29. listopada 2018., dostupno na: https://www.zeit.de/2018/44/dolmetscher-gericht-uebersetzung-wahrheit-justizministerium-honorare (30. listopada 2018.).

63 Dostupno na: https://www.hs-magdeburg.de/weiterbildung/weiterbildende-studienprogramme/dolmetschen-und-uebersetzen-fuer-gerichte-und-behoerden.html (15. studenoga 2018.).

64 U Hrvatskoj trenutačno djeluje čak šest udruga sudskih tumača od ukupno devet prevoditeljskih udruga. U Njemačkoj postoji samo pet te jedna krovna udruga Bundesverband der Dolmetscher und Übersetzer (BDÜ). Vidi Pym, A.; Grin, F.; Sfreddo, C.; Chan, A. L. J., The Status of the Translation Profession in the European Union. Final Report, 24 July 2012. EU: DGT/2011/TST, 2012., str. 36; Bajčić, op. cit. u bilj. 59, str. $234-235$.

65 Pravilnik o stalnim sudskim vještacima, Narodne novine, br. 38/2014, https://www. sudski-vjestaci.hr/fdsak3jnFsklKfa/dokumenti/Pravilnik_o_stalnim_sudskim_vjestacima-NN_38-14.pdf (10. listopada 2018.). 
skladu s čl. 4. Direktive ${ }^{66}$ jer se na njih u mnogim aspektima primjenjuju jednake odredbe kao i na suce (npr. odredbe o izuzeću). ${ }^{67}$ Koliko nam je poznato, samo Slovenija ${ }^{68}$ je zasad uvela zakonsku obvezu stručnih usavršavanja Izmjenama Pravilnika o sudskim tumačima 2012. godine, a u svjetlu Direktive 2010/64 o pravu na tumačenje i prevođenje. Izmjenama Pravilnika o sudskim tumačima ponovno imenovanje tumača uvjetovano je sudjelovanjem na najmanje pet stručnih usavršavanja, tri jezična i dva pravna, u roku od pet godina. ${ }^{69}$

\section{ZAKLJUČAK}

Presude ESLJP-a u predmetu Vizgirda i Suda EU-a u recentnim predmetima rasvjetljuju konkretne zadaće država članica u postupanju s osumnjičenicima i okrivljenicima koji ne razumiju jezik postupka. One apostrofiraju nužnost proaktivnog djelovanja nacionalnih sudova radi što učinkovitijeg prenošenja Direktive 2010/64 te ostvarivanja ciljeva dosljedne primjene prava i jamstava iz čl. 6. EKLJP-a i daljnjega razvoja minimalnih standarda utvrđenih EKLJP-om

${ }_{66}$ Kao što je navedeno u Uvodnoj izjavi 29, Direktivu treba ocjenjivati u svjetlu iskustva stečenog praksom. Ako je potrebno, ona se može i izmijeniti kako bi se unaprijedila jamstva koja se njome propisuju.

67 Nedavno je viši njemački sud Bundesgerichtshof (dalje u tekstu: BGH) kao drugostupanjski sud odlučivao o tome postoje li razlozi za izuzeće tumača zbog pristranosti. Tumačica je naime stavila ruku na rame žrtvi kaznenog djela silovanja tijekom iskazivanja. Primjenjujući iste odredbe koje se odnose na izuzeće vještaka i sudaca, BGH je odlučio da ne postoje objektivni razlozi za izuzeće. BGH, presuda od 4. srpnja 2018., 2 StR 485/17. ECLI:DE:BGH:2018:040718U2STR485.17.0.

68 Pravilnik o spremembah in dopolnitvah Pravilnika o sodnih tolmačih, Uradni list RS, 1/2012, 6. siječnja 2012.

Čl. 29.a Predložitev dokazil o strokovnem izpopolnjevanju:

“(1) Tolmač se mora v obdobju, določenem v četrtem odstavku 84. člena zakona, v skladu s šestim odstavkom 87. člena zakona za posamezni jezik udeležiti najmanj petih strokovnih izpopolnjevanj.

(2) Za predložitev dokazil o strokovnem izpopolnjevanju tolmačev, njihovem seznanjanju z novimi dognanji in metodami v stroki ter za oceno tega izpopolnjevanja in seznanjanja, se smiselno uporabljajo določila 5. člena tega pravilnika."

Vidi Kutin, Š.; Ivelja, I., Challenges Faced by the Court Interpreter Section of the Association of Translators and Interpreters of Slovenia in Light of the Directive 2010/64/EU, u: Bajčić, M.; Dobrić Basaneže, K. (ur.), Towards the Professionalization of Legal Translators and Court Interpreters in the EU, Cambridge Scholars Publishing, Newcastle upon Tyne, 2016., str. 23 - 40; Bajčić, M.; Osolnik Kunc, V., Why We Need CPDs: Translators as Experts in Disguise, Translation Europe Forum, 2017., dostupno na: https:// ec.europa.eu/info/sites/info/files/tef2017_baijcic-kunc_en.pdf (20. listopada 2018.). 
i Poveljom EU-a o temeljnim pravima. Kao što smo vidjeli, proaktivno djelovanje nacionalnih sudova podrazumijeva provjeravanje poznavanja jezika ne samo u negativnom smislu, utvrđujući kako osoba ne govori nacionalni jezik, već i utvrđujući da osoba zaista razumije jezik na kojem joj se tumači (kada je riječ o trećem jeziku). Također, imajući na umu dva kolosijeka prava na jezičnu pomoć iz Direktive 2010/64, s jedne strane pravo na tumačenje, s druge pravo na prijevod bitnih dokumenata, osobito valja pripaziti na to da se osobi ne oduzme mogućnost izvršavanja prava obrane, odnosno prava na podnošenje pravnog sredstva predviđenog nacionalnim pravom. Širokim tumačenjem valja odrediti kojim se kolosijekom može najučinkovitije jamčiti prava osumnjičenika i okrivljenika u kaznenom postupku.

Polazeći od analiziranih presuda, nacionalni sudovi moraju ispravnim tumačenjem pojma minimalnih pravila postupati iznimno oprezno s osumnjičenicima i okrivljenicima koji ne govore jezik postupka, i to tijekom čitavog kaznenog postupka. Pritom se nalaze na skliskom terenu jer postoji li i sjeme sumnje o tome da osumnjičenik ili okrivljenik ne razumije ili ne vlada dovoljno jezikom postupka, moraju poduzeti sve kako bi im omogućili djelotvorno pravo na obranu, što podrazumijeva ne samo pravo da razumiju sve što im se stavlja na teret, već i pravo da ih se razumije. Od država se očekuje da jamče minimalna pravila, pa i da ih prema potrebi proširuju kako bi osigurale višu razinu zaštite, čak i u situacijama koje nisu uređene Direktivom 2010/64 (Uvodna izjava 32). Činjenica da su države preuzele odredbe Direktive u nacionalno zakonodavstvo ne oslobađa ih dužnosti da poduzimaju sve moguće radnje, uključujući i odgovarajuću obuku te (obvezno) usavršavanje svih sudionika kaznenog postupka kako bi konkretna prava osumnjičenika i okrivljenika bila što djelotvornija.

\section{LITERATURA}

Bajčić, M., The Way Forward for Court Interpreting in Europe, u: Šarčević., S. (ur.), Language and Culture in EU Law: Multidisciplinary Perspectives, Ashgate, Surrey, 2015., str. $219-237$.

Crnić-Grotić, V.; Sgardelli Car, N., Ljudska prava u Europskoj uniji u praksi Europskog suda u Luksemburgu, Zbornik Pravnog fakulteta u Zagrebu, vol. 60, br. 5, 2010., str. 971 - 994.

Ćapeta, T., Interpretativni učinak europskog prava u članstvu i prije članstva u EU, Zbornik Pravnog fakulteta u Zagrebu, vol. 56, br. 5, 2006., str. 1443 - 1494.

Ivičević Karas, E.; Burić, Z.; Bonačić, M., Prava obrane u različitim stadijima hrvatskog kaznenog postupka: Rezultati istraživanja prakse, Hrvatski ljetopis za kazneno pravo i praksu, vol. 23, br. 2, 2016., str. $509-545$. 
Ivičević Karas, E.; Burić, Z.; Bonačić, M., Unapređenje procesnih prava osumnjičenika i okrivljenika u kaznenom postupku: pogled kroz prizmu europskih pravnih standarda, Hrvatski ljetopis za kaznene znanosti i praksu, vol. 23, br. 1, 2016., str. $11-58$.

Katschinke, L., An ISO Standard for Interpreting Services in Judicial Settings, u: Bajčić, M.; Dobrić Basaneže, K. (ur.), Towards the Professionalization of Legal Translators and Court Interpreters in the EU, Cambridge Scholars Publishing, Newcastle upon Tyne, 2016., str. 14-23.

Kutin, Š.; Ivelja, I., Challenges Faced by the Court Interpreter Section of the Association of Translators and Interpreters of Slovenia in Light of the Directive 2010/64/EU, u: Bajčić, M.; Dobrić Basaneže, K. (ur.), Towards the Professionalization of Legal Translators and Court Interpreters in the EU, Cambridge Scholars Publishing, Newcastle upon Tyne, 2016., str. $23-40$.

Pavišić, B., Komentar Zakona o kaznenom postupku, Templar-book, Šmrika, 2015.

Pym, A.; Grin, F.; Sfreddo, C.; Chan, A. L. J., The Status of the Translation Profession in the European Union. Final Report, 24 July 2012. EU: DGT/2011/TST, 2012., doi: 10.2782/63429

Spencer, D., Overview of Language Rights in the International Criminal Law Sentencing Models, International Journal of Semiotics of Law, 2018., str. 1 - 18, doi: 10.1007/s11196-018-9544-2 (3. listopada 2018.).

\section{IZVORI}

Direktiva 2010/64/EU Europskog parlamenta i Vijeća od 20. listopada 2010. o pravu na tumačenje i prevođenje u kaznenim postupcima, Službeni list L 280 od 26.10.2010.

Direktiva 2012/13/EU Europskog parlamenta i Vijeća od 22. svibnja 2012. o pravu na informiranje u kaznenom postupku, Službeni list L 142/1 od 1.6.2012.

Europska konvencija za zaštitu ljudskih prava i temeljnih sloboda, Narodne novine, Međunarodni ugovori, br. 18/1997, 6/1999, 14/2002, 13/2003, 9/2005, $1 / 2006,2 / 2010$

Gesetz zur Stärkung der Verfahrensrechte von Beschuldigten im Strafverfahren, (BeVRe$\mathrm{StG}$ ) od 2. srpnja 2013. (Službeni list I 1938, br. 34), dostupno na: https:// www.buzer.de/gesetz/10743/index.htm (5. listopada 2018.).

Okvirna odluka Vijeća 2002/584/PUP od 13. lipnja 2002. o Europskom uhidbenom nalogu i postupcima predaje između država članica (Službeni list L 190, 18.7.2002. str. 1.). 
Pravilnik o spremembah in dopolnitvah Pravilnika o sodnih tolmačih, (Uradni list RS 1/2012, od 6. siječnja 2012.)

Pravilnik o stalnim sudskim tumačima, Narodne novine br. 88/2008

Pravilnik o stalnim sudskim vještacima. Narodne Novine, br. 38/2014

Ugovor o funkcioniranju Europske unije (pročišćena inačica 2016.), Službeni list C 202 od 7. lipnja 2016.

Zakon o kaznenom postupku, Narodne novine, br. 152/08, 76/09, 80/11, 121/11, 91/12, 70/2017 Prekršajni zakon, Narodne novine br. 107/2007 i $39 / 2013$

Zakon o pravosudnoj akademiji, Narodne novine br. 153/2009 i 127/2010

Zakon o sudovima, Narodne novine 122/2010, 27/2011 i 130/2011

\section{Sudska praksa}

Berisha i Haljiti protiv Bivše Jugoslavenske Republike Makedonije, zahtjev br. 18670/03, presuda od 16. lipnja 2005.

Dvorski protiv Hrvatske, zahtjev br. 25703/11, presuda od 20. listopada 2015.

Güngor protiv Njemačke, zahtjev br. 31540/96, presuda od 17. svibnja 2001.

Hacioglu protiv Rumunjske, zahtjev br. 2573/03, presuda od 11. siječnja 2011.

Hermi protiv Italije, zahtjev br. 18114/02, presuda od 18. listopada 2006.

Husain protiv Italije, zahtjev br. 18913/03, presuda od 24. veljače 2005.

Ibrahim i drugi protiv Ujedinjene Kraljevine, zahtjev br. 50541/08 i drugi, presuda od 13. rujna 2016.

Irska protiv Ujedinjene Kraljevine, zahtjev br. 5310/71, presuda od 18. siječnja 1978.

Kamasinski protiv Austrije, zahtjev br. 9783/82, presuda od 19. prosinca 1989.

Mišljenje nezavisnog odvjetnika Yvesa Bota od 7. svibnja 2015. Predmet C-216/14, Kazneni postupak protiv Gavrila Covacija, ECLI:EU:C:2015:305

Mišljenje nezavisnog odvjetnika Nilsa Wahla od 11. svibnja 2017. Predmet C-278/16, Kazneni postupak protiv Franka Sleutjesa, ECLI:EU:C:2017:366

Odluka i Rješenje Ustavnog suda Republike Hrvatske broj: U-III-6559/2010 od 13. studenoga 2014.

Predmet C-216/14, Kazneni postupak protiv Gavrila Covacija, presuda od 15. listopada 2015., EU:C:2015:686

Predmet C-25/15, Kazneni postupak protiv Istvána Balogha, presuda od 9. lipnja 2016., ECLI:EU:C:2016:423 
Predmet C-278/16, Kazneni postupak protiv Franka Sleutjesa, presuda od 12. listopada 2017., ECLI:EU:C:2017:757

Presuda BGH od 4. srpnja 2018., 2 StR 485/17. ECLI:DE:BGH:2018:040718 U2STR485.17.0

Uçak protiv Ujedinjene Kraljevine, zahtjev br. 44234/98, presuda od 24. siječnja 2002.

Vizgirda protiv Slovenije, zahtjev br.: 59868/08, presuda od 28. kolovoza 2018.

\section{Ostali izvori}

Bajčić, M.; Osolnik Kunc, V., Why We Need CPDs: Translators as Experts in Disguise. Translation Europe Forum, 2017., dostupno na: https://ec.europa.eu/ info/sites/info/files/tef2017_baijcic-kunc_en.pdf (20. listopada 2018.)

Dolmetscher: Bablyon im Gericht, Die Zeit, 29. listopada 2018., dostupno na: https://www.zeit.de/2018/44/dolmetscher-gericht-uebersetzung-wahrheit-justizministerium-honorare (30. listopada 2018.)

Jačanje procesnih prava osumnjičenika i okrivljenika u kaznenom postupku u Hrvatskoj: Preporuke za unapređenje normativnog okvira i prakse, dostupno na: http://www.hpc. hr/wp-content/uploads/2017/03/\%E2\%80\%9EPreporuke-za-unapre\%C4\%9lenje-normativnog-okvira-i-prakse\%E2\%80\%9C.pdf (1. listopada 2018.)

Katschinka, L., Deadline for transposition of EU Directive 2010/64 expired, dostupno na: http://www.nrpsi.org.uk/downloads/EULITA_Deadline_for_EU_ Directive_transposition_expired.pdf (4. listopada 2018.) 


\section{Summary}

\section{Martina Bajčić*}

\section{RIGHT TO INTERPRETATION AND TRANSLATION OF ACCUSED PERSONS IN CRIMINAL PROCEEDINGS THROUGH THE LENS OF RECENT CASE LAW OF THE ECHR AND THE CJEU}

Under Article 6 of the European Convention on Human Rights, anyone facing a criminal charge must be provided with the services of an interpreter free of charge if he or she does not understand the language of the proceedings. Despite the fact that all EU Member States are signatories to the Convention, they do not meet the above requirement in a uniform way. However, inconsistent implementation of the rights and guarantees enshrined in Article 6 of the Convention runs counter to the aims of strengthening mutual trust and confidence in the criminal justice systems of all Member States and in turn furthering judicial cooperation in the EU.

Observed in this light, settled case law of the ECHR therefore plays an important role in bridging the differences among the Member States in terms of the protection of legal standards guaranteed under the Convention. By the same token, through its settled case law the CJEU likewise elucidates and develops the notion of common minimum rules pertaining to free and adequate linguistic assistance to all suspected or accused persons who do not speak or understand the language of criminal proceedings, as set out in Directive 2010/64 on the right to interpretation and translation.

Against this backdrop, this paper analyses recent judgments of the ECHR and the CJEU. Blazing a new trail, the latter courts call on the Member States not only to allow for an effective exercise of the right to interpretation and translation, but to guarantee the best protection of this right in order to safeguard the fairness of proceedings. What is more, the Member States should extend the rights set out in the Directive on the right to interpretation and translation in order to provide a higher level of protection also in situations not dealt with in the Directive.

Key words: right to interpretation and translation, criminal proceedings, Directive $2010 / 64$

\footnotetext{
* Martina Bajčić, Ph. D., Assistant Professor, Faculty of Law, University of Rijeka, Hahlić 6, Rijeka; martina.bajcic@pravri.hr;

ORCID ID: orcid.org/0000-0003-0654-6779
} 